\title{
年間特集「火」: 技術論文
}

\section{フィンガーサイズ原子発光検出器を備えたガスクロマトグラフによる 重水素化内標準物質を用いる水道水中の芳香族污染物質の定量}

\author{
平野龍太郎 ${ }^{1}$, 中釜 達朗 ${ }^{\circledR 2}$, 中 嶋 秀 ${ }^{1}$, 曽 湖 烈 ${ }^{1}$, 内山 一美 ${ }^{1}$
}

\begin{abstract}
ラジオ波ヘリウムプラズマを用いたフィンガーサイズ原子発光検出器（AED）を備えたガスクロマトグラ フを使用し, 芳香族污染物質（トルエン，クロロベンゼン，1,2-ジクロロベンゼン及び 1,4-ジクロロベンゼ ン）及びそれらの重水素化体を定量した。 小型 CCD 分光器（波長分解能 $0.035 \mathrm{~nm}$ ）を用いたとき, 656.28 $\mathrm{nm}$ と $656.10 \mathrm{~nm}$ の水素と重水素の原子発光は完全にスペクトル分離できなかったが, キャピラリーガスク ロマトグラフ $(\mathrm{GC})$ カラムを用いて芳香族污染物質と対応する重水素化体とを完全にクロマトグラフィー分 離することにより，原子発光を別々に測定できた．メークアップ（プラズマ）ガス流量, 印加電力及び周波 数をそれぞれ $5 \mathrm{~mL} \mathrm{~min}{ }^{-1}, 20 \mathrm{~W}$ 及び $220 \mathrm{kHz}$ と最適化したとき, トルエンとトルエン $-d_{8}$ に含まれる水素と

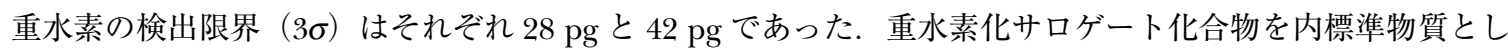
て用い,ヘッドスペース固相マイクロ法により抽出した水道水に含まれる芳香族污染物質を GC-AED により ppb レベルで定量することに成功した.
\end{abstract}

\section{1 緒言}

同位体置換体を標準物質として用いた定量法 ${ }^{1) \sim 5)}$ は, 複 雑なマトリックスを持つ環境試料中の微量污染物質の定量 分析において極めて有用な方法である。同位体元素によっ て置換された物質の化学的な挙動は元の物質とほぼ同等で あることから，抽出・分離・精製課程ではほぼ同じ挙動を 示し，マトリックス成分の干渉が小さい. しかし，ガスク ロマトグラフィー $(\mathrm{GC})$ により定量する場合, 水素炎イオ ン化型検出器（FID）や熱伝導度検出器（TCD）などの沉 用検出器では同位体置換体と元の化合物を分別定量するの は困難である。一般に測定対象物質とその同位体置換体の クロマトグラフィー分離は難しいため, 検出する段階で同 位体相互の識別を行う必要がある.

質量分析計 $(\mathrm{MS})$ を GC 検出器に用いると同位体置換体 と元の物質との分別が容易で高精度な定量が期待される. この場合重水素 $(\mathrm{D})$ P ${ }^{13} \mathrm{C}$ 置換体を用いることが多く, 環 境試料や生体試料の高精度定量に利用されている.

一方, 原子発光検出器 (AED) を用いた GC 分析 ${ }^{6) \sim 27)}$ は, 原子固有の発光波長とその強度から, GC カラムから溶離 した成分中の元素組成の分析が可能である．また，同位体 相互でその原子発光スペクトルが若干異なることから, 高

\footnotetext{
${ }^{\circledR}$ E-mail : nakagama.tatsurou@nihon-u.ac.jp

${ }^{1}$ 首都大学東京大学院都市環境科学研究科分子応用化学専攻： 192-0397 東京都八王子市南大沢 1-1

2 日本大学生産工学部応用分子化学科 : 275-8575 千葉県習志野 市泉町 1-2-1
}

分解能を持つ分光器を用いればスペクトル上での分離も可 能で, 同位体置換体を内標準物質として用いた定量も可能 である。

AED はプラズマ源の種類によっていくつかのタイプに 分類される.すなわち, マイクロ波誘導プラズマ $(\mathrm{MIP})^{4) \sim 12)}$, ラジオ波プラズマ $(\mathrm{RFP})^{13) \sim 20) 24) \sim 28)}$, 誘導結 合プラズマ $(\mathrm{ICP})^{2)}$, 直流放電プラズマ $(\mathrm{DCP})^{21) \sim 23)}$ など が報告されている. 現在, GC用として市販されている AED は MIP を用いている. MIP では放電電極由来のバッ クグラウンド発光がないため, 高い純度のプラズマが得ら れ, 高感度である. 一方, 大量のメークアップガス, 放電 管の冷却, 水素や酸素などの反応ガスやパージガスを必要 とする. また試料溶出時にプラズマが不安定化することも ある. MIP-AEDにおいて同位体置換体を内標準物質として 用いた定量法は, 既に報告されている. しかし通常同位体 標識体と元の化合物は同時に溶出するため, 実試料に応用 するためには高分解能検出器を用いるか, 異なった発光波 長を用いるなどの工夫が必要である. 通常, 発光スペクト ル強度はバックグラウンド信号を差し引いた後の值を用い るため，極端に異なった波長ではバックグラウンド信号の 変動をキャンセルできない場合がある.

他方, 直接放電型 RFP-AED においては, プラズマ電極由 来のバックグラウンド発光, 電極材料の光学空への付着に よるメンテナンスの必要性などの問題があるものの, プラ ズマ管の空冷や反応ガス・パージガスなどが不要で, メー クアップガスも少量でよい等の利点がある．また，装置の 


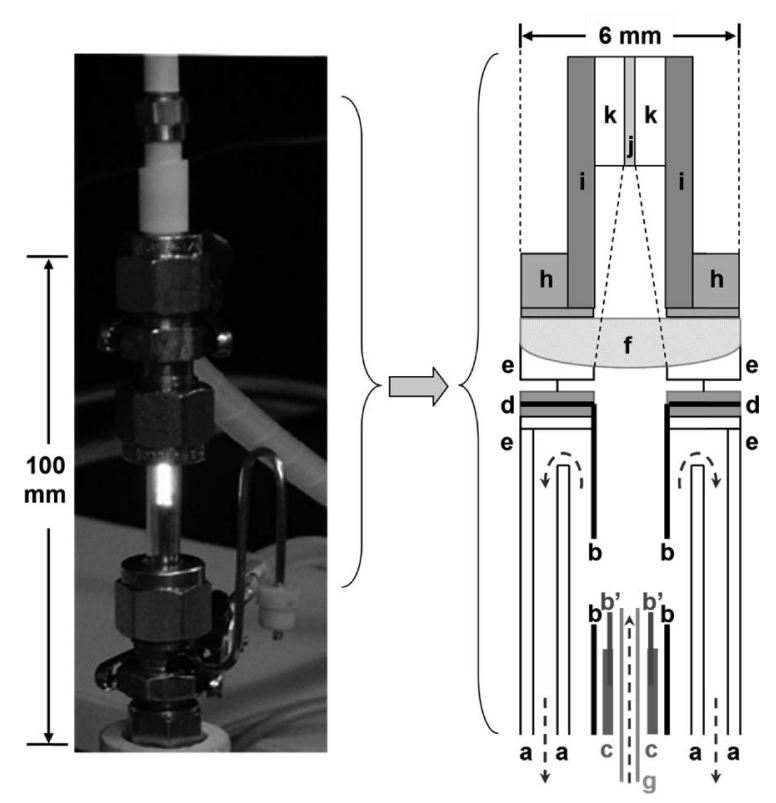

Fig. 1 Finger-sized AED used in this study a : quartz tubes ; b, b' : platinum tubes (electrodes); c : stainless steel tube ; $d$ : stainless steel O-ring ; e : PTFE O-ring ; $\mathrm{f}$ : Plano-convex lens ( $\mathrm{f}=18 \mathrm{~mm}) ; \mathrm{g}$ : exit of capillary column ; h : stainless steel union ; i : ceramic tube $; \mathrm{j}$ : optical fiber (core diameter $=400$ $\mu \mathrm{m}) ; \mathrm{k}$ : stainless-sleeve. Dotted arrows indicate flow of the sample and plasma (helium) gas.

小型化も容易である。これまで著者らの報告 ${ }^{24)}$ 28) を含め ていくつかの研究例はあるものの市販の装置はいまだにな い. RFP-AED をこのような内標準法に適用することも可能 であるが, これまで報告されていない.

本研究では, 著者らの開発した CCD 型マルチチャンネ ル検出器を備えた小型 RFP-AEDを GC 検出器として用い, 重水素ラベル化した内標準物質を用いて水道水中の芳香族 污染物質であるトルエン及びクロロベンゼン類のヘッドス ペース固相抽出 (HS-SPME)-GC-AED 分析に適用できるか を検討した。

\section{2 実験}

\section{$2 \cdot 1$ 試 薬}

モデル試料としてトルエン，クロロベンゼン，1,2-ジク ロロベンゼン及び 1,4-ジクロロベンゼンを用いた. トルエ ン及びその重水素置換体であるトルエン $-d_{8}$ は関東化学製 を, クロロベンゼン，1,2-ジクロロベンゼン及び 1,4-ジク ロロベンゼンは東京化成工業製を, これらの重水素置換体 であるクロロベンゼン $-d_{5}, 1,2-$ ジクロロベンゼン $-d_{4}$ 及び 1,4-ジクロロベンゼン - $d_{4}$ はスペルコ製をそれぞれ用いた. 試料溶媒にはメタノールを用いた。

\section{$2 \cdot 2$ 装 置}

本研究では著者らが開発した既報の RFP-AED（フィン ガーサイズ $\mathrm{AED}^{28)}$ ) を用いた. AEDの構造を Fig. 1 に示 す.上下 2 本の白金管（図中 b, 内径 $1.8 \mathrm{~mm}$, 外径 2.0 $\mathrm{mm}$ ）を設置して放電用電極とし, 電極間距離は $5 \mathrm{~mm}$ と した。 上部 (高圧側) 電極の上に平凸レンズ（図中 $\mathrm{f}$, 外 径 $6.0 \mathrm{~mm}, \mathrm{f}=18 \mathrm{~mm}$ ) を設置し, プラズマ内の発光を集 光して光ファイバー (P400-2-VIS/NIR，コア径 $400 \mu \mathrm{m}$, Ocean Optics 製) によりマルチチャンネル CCD 分光器 (HR-4000, 測定波長範囲：596.1 706.17 nm, 波長分解 能： $0.035 \mathrm{~nm}$, Ocean Optics 製) に導いた. 分光器はパー ソナルコンピュータに接続し, 得られた信号をソフトウエ ア (OOIBase32, Ocean Optics 製) により解析した。測定 の際, 分光器の積分時間は $100 \mathrm{~ms}$ とした. 平凸レンズが 収納してあるステンレス鋼製ユニオン（図中 h）はラジオ 波発生装置（RF200-OR251M，東京ハイパワー製）に接続 した.下部 (接地) 電極の内部に別の白金管（図中 b', 内 径 $0.8 \mathrm{~mm}$, 外径 $1.0 \mathrm{~mm}$, 長さ $5 \mathrm{~mm}$ ）をステンレス鋼管 （内径 $0.8 \mathrm{~mm}$, 外径 $1 / 16$ インチ, 長さ $200 \mathrm{~mm}$ ) 上の溝 (図中 $\mathrm{c}$, 幅 $1.0 \mathrm{~mm}$, 深さ $3 \mathrm{~mm}$ ) 内に設置し, 先端を約 $1 \mathrm{~mm}$ 電極から突き出るようにした. この白金管は溶媒の 導入などによりプラズマが不安定化するのを防止する役割 をする.プラズマガス（He，純度 $99.999 \%$ 以上）及び試 料はこの白金管内から供給した.

プラズマへの外気の漏れ込みを防ぐため, 石英製放電管 (図中 a, 内径 $4.5 \mathrm{~mm}$, 外径 $5.9 \mathrm{~mm}$ 及び内径 $2.5 \mathrm{~mm}$, 外 径 $3.9 \mathrm{~mm}$ ） は二重管構造とした．外側放電管はグラファ イトフェラルを用いて，上下に設置したステンレス製ユニ オンにより密閉した. 下部のユニオンにはプラズマガスを 排出するためのドレインパイプを設置した.

GCには島津製作所製 GC-17Aを用い, キャピラリーカラ ム (DB-5MS, 長さ $60 \mathrm{~m}$, 内径 $0.32 \mathrm{~mm}$, 膜厚 $0.25 \mu \mathrm{m}$, $\mathrm{J} \& \mathrm{~W}$ 製) を接続した. キャリヤーガス流量を $1.3 \mathrm{~mL} \mathrm{~min}^{-1}$, 試料導入口温度及び検出器温度を共に $250{ }^{\circ} \mathrm{C}$ に設定した. GC 分離は温度プログラミング法により行い, カラム温度 を $40{ }^{\circ} \mathrm{C}$ で 5 分間保持した後, $5{ }^{\circ} \mathrm{C} \mathrm{min}^{-1}$ で昇温し, $140{ }^{\circ} \mathrm{C}$ で一定とした。 なお，試料溶液はマイクロシリンジ（10 $\mu \mathrm{L}, \mathrm{SGE}$ 製) を用いて $1 \mu \mathrm{L}$ 導入し，スプリット比は $1: 65$ として測定を行った.

\subsection{HS-SPME}

水道水中に存在する芳香族炭化水素類の抽出は HS-SPME により行った ${ }^{29)}$. SPME はマニュアルタイプの SPME ホルダー（57330-U, スペルコ製）に揮発性有機化合 物（VOC）抽出用ファイバー（膜厚 $100 \mu \mathrm{m}, 57300-\mathrm{U}$, ス ペルコ製) を取り付けて行った。 まず，一定量の重水素置 換体を内標準物質として，またそれぞれに対応する標準物 


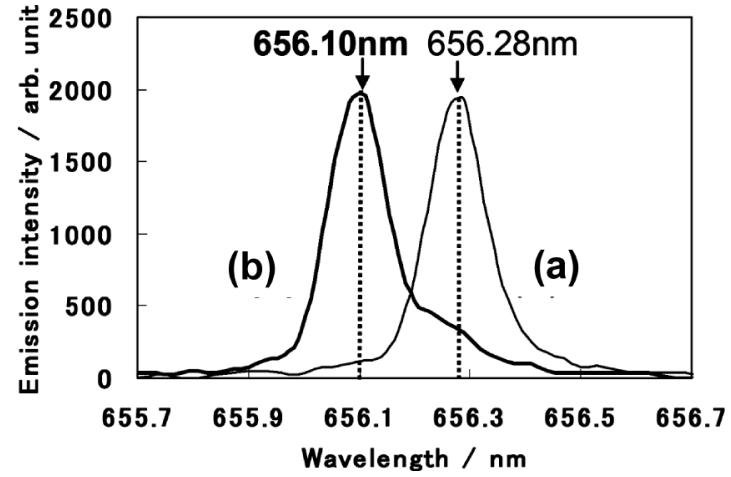

Fig. 2 Atomic emission spectra for hydrogen in toluene (a) and deuterium in toluene- $d_{8}(\mathrm{~b})$ obtained by using the AED equipped with a GC

Spectra were fitted with a spline approximation.

質を添加した標準試料溶液 $(5 \mathrm{~mL})$ を SPME 用バイアル瓶 (40 mL，Type27184，スペルコ製）に入れ，シリコンセプ タム及びキャップで密封した。これを高速液体クロマトグ ラフィー（HPLC）用オーブン（CTO-10AC，島津製作所 製）中 $40{ }^{\circ} \mathrm{C}, 3$ 分間保持し平衡化した. 平衡化後, バイア ル瓶のヘッドスペースに抽出用ファイバーを差し入れて 10 分間保持することにより HS-SPME を行った.

\section{3 結果及び考察}

\section{$3 \cdot 1$ 水素及び重水素に由来する原子発光線の測定}

水素及び重水素に由来する発光波長の選択は, 精確な定 量を行う上で極めて重要である. 可視域における水素原子 の発光波長は $656.28 \mathrm{~nm}$ ( $\mathrm{H}_{\alpha}$ 線), $486.13 \mathrm{~nm}$ ( $\mathrm{H}_{\beta}$ 線), $434.05 \mathrm{~nm}\left(\mathrm{H}_{\gamma}\right.$ 線 $)$ 及び $410.17 \mathrm{~nm}\left(\mathrm{H}_{\delta}\right.$ 線 $)$ などが知られ ており, 重水素は各々の波長より少し短波長側に発光線を 有する ${ }^{30}$. 使用した分光器で測定可能な波長は $656.28 \mathrm{~nm}$ (水素) であり, 対応する重水素の発光波長は $656.10 \mathrm{~nm}$ (重水素) である.

実際に, トルエン及びトルエン $-d_{8}$ 溶液を GC に導入し, フィンガーサイズ AEDにより分光器の測定波長領域 （596.1〜706.2 nm）の発光スペクトルを測定したところ， 上記波長にそれぞれの発光を確認した. Fig. 2 に得られた 水素及び重水素の発光スペクトルを示す．なお，このスペ クトルは試料溶出時に取得したスペクトルからバックグラ ウンドスペクトルを差し引いた結果である. 使用した波長 分解能の分光器では水素と重水素の発光スペクトルの識別 は可能であったが，完全分離は困難であった。このスペク トルプロファイルからそれぞれの発光強度を補正計算する ことにより定量できる可能性はあるが, バックグラウンド 発光が変化すると精確な定量は困難である. 本研究では, 測定対象物質とその重水素置換体を GC 分離した後, フィ ンガーサイズ AED により水素及び重水素の発光をそれぞ

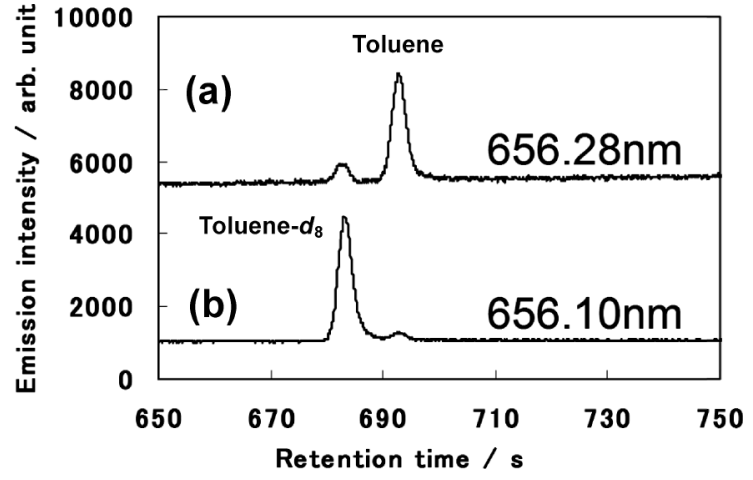

Fig. 3 Gas chromatograms of the mixed solution of toluene and toluene- $d_{8}$ obtained at hydrogen [656.28 $\mathrm{nm}$ (a)] and deuterium [656.10 nm (b)] emission lines

Sample : toluene (the amount of hydrogen detected : $0.33 \mathrm{ng}$ ); toluene- $d_{8}$ (the amount of deuterium detected : $0.61 \mathrm{ng}$ )

れ測定することにより定量することとした．

Fig. 3 にモデル試料であるトルエンとトルエン $-d_{8}$ をそれ ぞれ対応する波長で測定したときのガスクロマトグラムを 示す.トルエンとトルエン $d_{8}$ はクロマトグラム上で分離 が達成された．水素の発光波長（656.28 nm）に扔けるト ルエン $-d_{8}$ 溶出時, 重水素の発光波長 $(656.10 \mathrm{~nm})$ に扔け るトルエン溶出時にそれぞれ小さなピークが認められた。 この原因は, Fig. 2 に示したような水素及び重水素相互の スペクトル干渉によるものと考えられる，以上の結果よ り，GC-フインガーサイズ AEDによる重水素化内標準物質 を用いた定量が可能であることを示唆した。

\section{$3 \cdot 2$ AED 条件の最適化}

本研究ではメークアップガス流量, 印加電力及び印加周 波数について，GC-AED により測定される水素及び重水素 由来の発光強度（ガスクロマトグラムに拀けるトルエン及 びトルエン - $d_{8}$ のピーク面積）に及ぼす影響を検討するこ とにより, AED 条件の最適化を行った。

メークアップガス流量の水素及び重水素の発光強度に対 する影響を Fig. 4 (a) 及び Fig. 5 （a）に示す. 測定された 水素及び重水素の発光強度はメークアップガス流量の増加 に伴い徐々に減少した。これはプラズマガス流量の増加に 伴い, 試料のプラズマ内での滞在時間が減少することによ りそれぞれの原子化率が低下したのが原因と考えられる. また，本研究で用いたフィンガーサイズ AEDに扔いて， GC カラムから溶離した試料成分はプラズマに導入される 直前にメークアップガスと混合される．したがって，メー クアップガスによる試料の希釉も測定強度低下の一因と考 えられる。 ノイズレベルはメークアップガス流量に依存せ ずほぼ一定だったため, S/N 比もメークアップガス流量の 


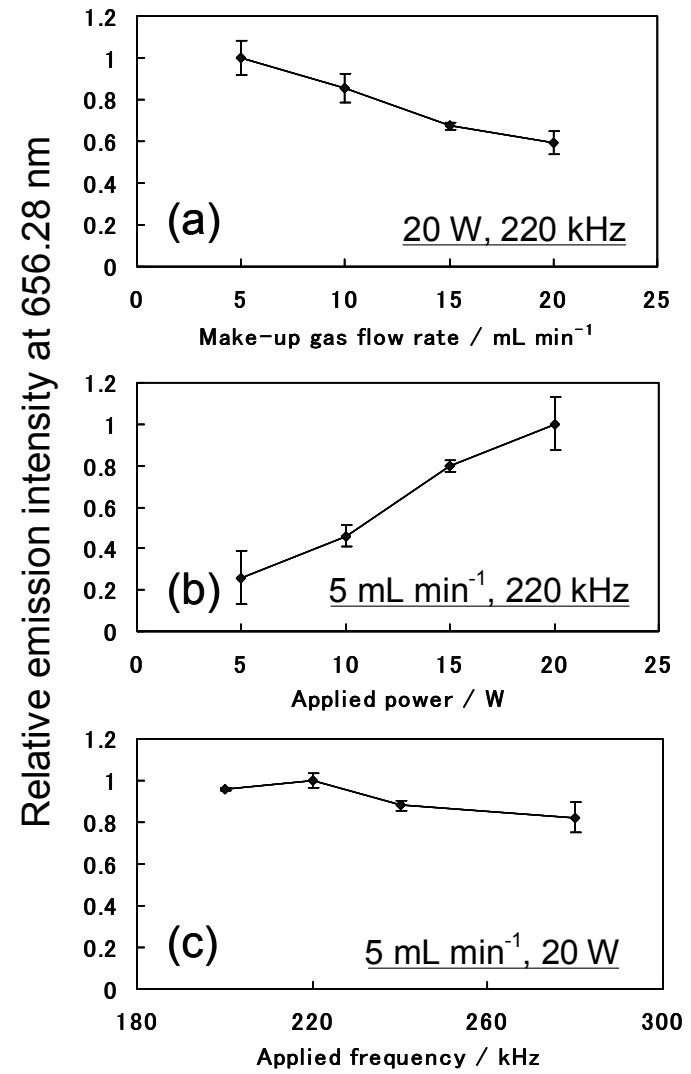

Fig. 4 Effects of the make-up gas flow rate (a), applied power (b) and applied frequency (c) on the emission intensity at the hydrogen emission line $(656.28 \mathrm{~nm})$

Sample: toluene (the amount of hydrogen detected : 0.67 ng.)

増加に従って低下した。 しかしながら，プラズマガス流量 が $5 \mathrm{~mL} \mathrm{~min}{ }^{-1} よ り$ 小さい場合, プラズマの点灯位置が変 化したり，プラズマ自体が不安定になったりすることが

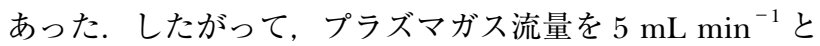
して以後の検討を行った.

水素及び重水素の発光強度に対する印加電力の影響を Fig. 4（b）及び Fig. 5（b）に示した. 印加電力の増加につ れてピーク面積及び $\mathrm{S} / \mathrm{N}$ 比はそれぞれ増加した。 しかしな がら, $25 \mathrm{~W}$ 以上の印加電力ではプラズマの安定性が極端 に低下し，安定な測定を行うことができなかった。一方， $5 \mathrm{~W}$ 未満の印加電力においても安定なプラズマを得ること ができなかった．以上の結果から，測定に最適な印加電力 は $20 \mathrm{~W}$ と判断した.

印加周波数については $200 \mathrm{kHz}$ から $280 \mathrm{kHz}$ の間で検討 した，その結果，検討した周波数領域では，水素及び重水 素の発光強度, $\mathrm{S} / \mathrm{N}$ 比ともに特に大きな変化はみられな かった [Fig. 4 (c) 及び Fig. 5 (c)]. 本研究では, $220 \mathrm{kHz}$ を印加周波数として以下の検討を行った.

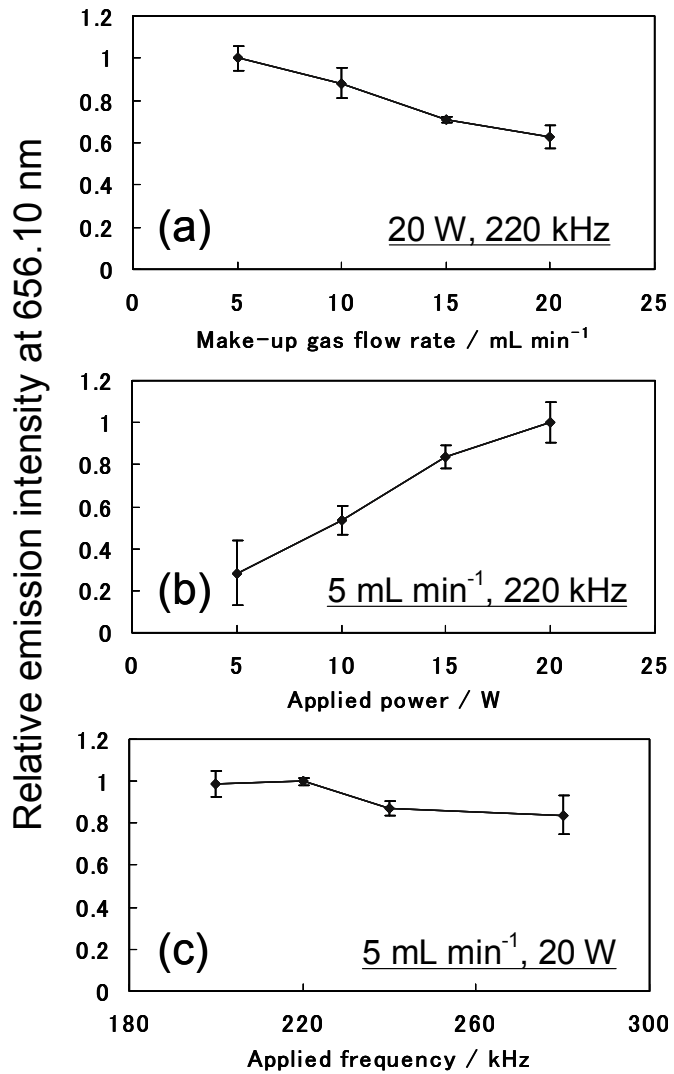

Fig. 5 Effects of the make-up gas flow rate (a), applied power (b) and applied frequency (c) on the emission intensity at the deuterium emission line $(656.10 \mathrm{~nm})$

Sample : toluene- $d_{8}$ (The amount of deuterium detected : $1.20 \mathrm{ng}$ )

\section{$3 \cdot 3$ AED の検出特性}

本研究では，GC-AEDにより得られたガスクロマトグラ ムにおけるトルエン及び 3 種類のクロロベンゼン, 及びそ れらの重水素置換体のピーク面積から水素及び重水素の検 出特性を評価した.

Fig. 6 にそれぞれのモデル試料を各 $100 \mathrm{ppm}$ とした混合 溶液を最適な AED 条件下で GC-AED 測定して得られたク ロマトグラムを示す. Fig. 6 （a）はトルエン及び 3 種類の クロロベンゼンの混合溶液を水素の発光波長 $(656.28 \mathrm{~nm})$ により測定した場合，Fig. 6（b）は重水素置換体の混合溶 液を重水素の発光波長 $(656.10 \mathrm{~nm})$ により測定した場合 のクロマトグラムである。 このとき，トルエン，クロロべ ンゼン，1,4-ジクロロベンゼン及び 1,2-ジクロロベンゼン の検出器の到達する水素量はそれぞれ $0.27,0.14,0.085$ 及 び $0.082 \mathrm{ng}$ であり, それぞれの重水素置換体であるトルエ ン $-d_{8}, \quad$ クロロベンゼン $-d_{5}, 1,4$ - ジクロロベンゼン $-d_{4}$ 及び 1,2-ジクロロベンゼン - $d_{4}$ の検出器の到達する重水素量は それぞれ $0.49,0.26,0.17$ 及び $0.17 \mathrm{ng}$ である. ベースラ インのノイズレベルは Fig. 6 (a) が比較的大きかったが, 外気の漏れこみ，あるいはメークアップガス中に不純物と 
して含まれる水素あるいは水蒸気などに由来する水素の原 子発光が原因と考えられる.

トルエンとクロルベンゼン類, 及びそれらの重水素置換 体について, Fig. 6 の GC-AED 条件で得られた各検量線の 直線性と分析精度について Table 1 に示す。試料濃度 200, 100,50 及び $25 p p m$ の 4 点検量線において, 検出器に到達 する水素及び重水素量 $(n g)$ と測定された発光強度（クロ

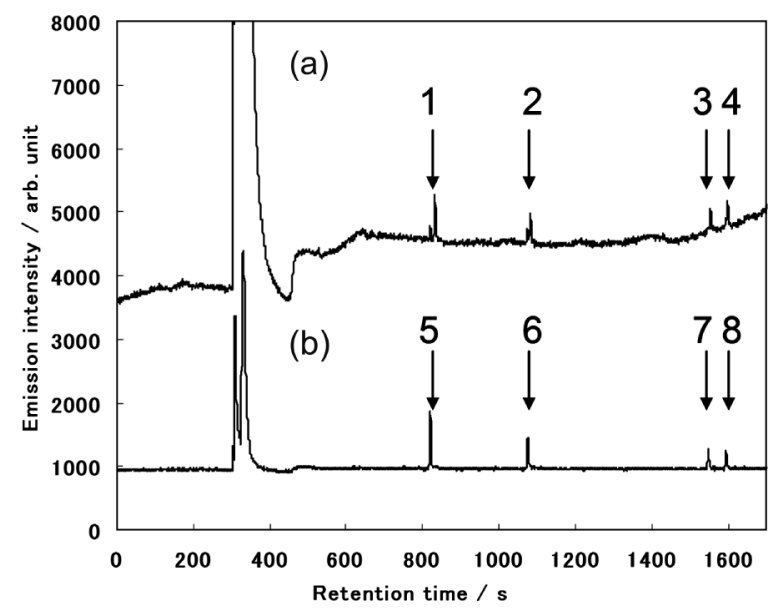

Fig. 6 GC-AED chromatograms of the test sample solutions obtained at hydrogen $[656.28 \mathrm{~nm}$ (a)] and deuterium [656.10 nm (b)] emission lines

1: toluene (104 ppm); 2 : chlorobenzene (104 ppm); 3 : 1,4-dichlorobenzene (102 ppm); 4 : 1,2-dichlorobenzene (105 ppm); 5 : toluene- $d_{8}(98 \mathrm{ppm}) ; 6$ : chlorobenzene- $d_{5}$ (97 ppm); 7 : 1,4-dichlorobenzene- $d_{4}$ (99 ppm); 8 : 1,2-dichlorobenzene- $d_{4}$ (99 ppm). Chromatographic condition : column, DB-5MS $(0.32 \mathrm{~mm}$ i.d. $\times 60 \mathrm{~m}$ long, $0.25 \mu \mathrm{m}$ d.f.); column temperature programmed, $5 \mathrm{~min}$ at $40{ }^{\circ} \mathrm{C}, 5{ }^{\circ} \mathrm{C} \min ^{-1}$ to $140{ }^{\circ} \mathrm{C}$; injection temperature, $250{ }^{\circ} \mathrm{C}$; injection volume, $1 \mu \mathrm{L}$; split ratio, $1: 65$. AED condition : flow rate of plasma gas ; $5 \mathrm{~mL} \mathrm{~min}^{-1}$, applied power ; $20 \mathrm{~W}$, applied frequency ; $220 \mathrm{kHz}$.
マトグラムのピーク面積）との間に良好な直線性（ $R^{2}>$ 0.99)が認められた. 同一濃度の試料溶液において測定さ れた発光強度の相対標準偏差 [RSD $(\%), n=3]$ の最小 值と最大值をモデル化合物ごとに Table 1 に示した. 再現 性については重水素検出の方が比較的良好であったが, こ れは水素検出時のベースラインのノイズレベルが比較的大 きく, 再現性低下の原因になっていることが示唆される.

本 GC-AEDにおける化合物量としての検出限界值は化合 物量として ng からサブ ng レベルであった. トルエン及び トルエン $-d_{8}$ の結果から, 水素及び重水素量としての検出 限界值を算出したところ，それぞれ $28 \mathrm{pg}$ 及び $42 \mathrm{pg}$ で あった。

\section{$3 \cdot 4$ 原子発光応答の分子構造依存性}

GC-AED において, 理想的には試料の分子構造にかかわ らず，元素量に応じた信号強度を得ることが望ましい。し かし，実際の測定においては化合物の分子構造によって原 子量あたりの発光強度が異なる場合がある. 直接放電型へ リウムプラズマは高い電子温度を持つ（～5000 K）が, ガ ス温度は $1400 \mathrm{~K}$ 程度と低く, このため試料分子の原子化 過程が原子発光の律速になるために分子構造依存性が生じ ると考えられる. 本研究で用いた芳香族炭化水素は類似し た構造を持つため, 構造によって極端な発光強度の違いは ないことが予想された. Table 1 における直線の傾きは水 素及び重水素の単位質量あたりの発光強度を示している. トルエン及びトルエン $-d_{8}$ で得られた検量線の傾きをそれ ぞれ 1 としたときの他のモデル化合物における相対值を Table 1 に示した. 水素検出については相対值が 0.96 1.07 , 重水素検出については $0.92 \sim 1.05$ の範囲であった. 測定誤差を考慮すれば測定濃度の範囲では発光強度の分子 構造依存性はほとんどないと考えられる.

Table 1 Linearity of the calibration curve and analytical precision for test compounds by the proposed method

\begin{tabular}{|c|c|c|c|c|}
\hline \multirow{2}{*}{$\begin{array}{c}\text { Test } \\
\text { compound }\end{array}$} & \multicolumn{2}{|c|}{ Linearity $^{\text {a) }}(n=4)$} & \multirow{2}{*}{$\operatorname{RSD}^{\mathrm{b})} / \%(n=3)$} & \multirow{2}{*}{$\begin{array}{c}\text { Detection limit }{ }^{c)} / \mathrm{ng} \\
(3 \sigma, n=3)\end{array}$} \\
\hline & Slope (relative value) & $R^{2}$ & & \\
\hline Toluene & $33254(1.00)$ & 0.9973 & $1.2 \sim 14.0$ & 0.32 \\
\hline $\mathrm{CB}$ & $35644(1.07)$ & 0.9978 & $1.6 \sim 8.0$ & 0.30 \\
\hline 1,2-DCB & $33410(1.00)$ & 0.9912 & $8.0 \sim 19.4$ & 1.41 \\
\hline 1,4-DCB & $32060(0.96)$ & 0.9953 & $6.3 \sim 12.0$ & 1.37 \\
\hline Toluene- $d_{8}$ & $18765(1.00)$ & 0.9978 & $1.1 \sim 8.7$ & 0.26 \\
\hline CB- $d_{5}$ & $19618(1.05)$ & 0.9968 & $2.6 \sim 7.5$ & 0.21 \\
\hline $1,2-\mathrm{DCB}-d_{4}$ & $17304(0.92)$ & 0.9956 & $4.7 \sim 12.1$ & 1.16 \\
\hline $1,4-\mathrm{DCB}-d_{4}$ & $17980(0.96)$ & 0.9973 & $1.3 \sim 5.0$ & 0.76 \\
\hline
\end{tabular}

$\mathrm{CB}$, chlorobenzene ; DCB, dichlorobenzene. a) The relationship between the amount of $\mathrm{H}$ or $\mathrm{D}$ detected (ng) and the average emission intensity (peak area in chromatogram obtained) for each of three measurements ; b) Minimum and maximum values in each concentration tested ; c) for each test compounds 
Table 2 Determination of test aromatic hydrocarbons in tap water by the proposed method

\begin{tabular}{ccccr}
\hline Test compound & Spiked conc./ppb & $\begin{array}{c}\text { Relative emission } \\
\text { intensity/(D/H) }\end{array}$ & $\begin{array}{c}\text { Relative concentration/ } \\
(\mathrm{D} / \mathrm{H})\end{array}$ & Recovery/\% ${ }^{\mathrm{a})}$ \\
\hline Tap water & 0 & n.d. & n.d. \\
\hline+ Toluene & 200 & 1.10 & 1.05 & $95.6(2.3)$ \\
+ CB & 200 & 1.10 & 1.09 & $91.8(8.6)$ \\
+ 1,2-DCB & 200 & 1.02 & 0.96 & $103.2(7.1)$ \\
$+1,4-\mathrm{DCB}$ & 200 & 1.00 & 1.06 & $94.9(6.9)$ \\
\hline
\end{tabular}

CB, chlorobenzene ; DCB, dichlorobenzene. a) Values in brackets are RSD values for recovery in four HS-SPME-GC-AED measurements.

\section{$3 \cdot 5$ 水道水中の芳香族炭化水素の定量}

本法を水道水中の芳香族炭化水素類の定量に応用した. まず, 首都大学東京 9 号館 3 階分析化学研究室の水道水 5.0 mL を採取して HS-SPME を行った後, GC-AED 測定した. その結果, 水道水からは芳香族炭化水素類は検出されな かった。

さらに本法の適用性を明らかにするために，既知量の芳 香族炭化水素類を水道水に添加し, さらに対応する重水素 置換体を内標準物質として加えて添加回収実験を行った. すなわち, トルエン, クロロベンゼン, 1,2-ジクロロベン ゼン及び 1,4-ジクロロベンゼンをそれぞれ試料水に最終濃 度 $200 \mathrm{ppb}$ となるように添加した。 この濃度は, WHOの ガイドライン值（トルエン： $700 \mathrm{ppb,} \mathrm{クロロベンゼン} \mathrm{:}$ $300 \mathrm{ppb}, 1,2-$ ジクロロベンゼン：1000 ppb 及び 1,4-ジク

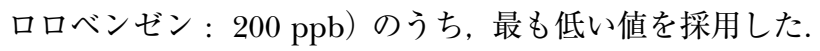
それぞれの内標準物質として重水素置換体を同様に最終濃 度 $200 \mathrm{ppb}$ となるように添加した。

Table 2 に内標準法により求めた添加回収実験の結果を 示す. 試料に添加した 4 種類のモデル試料の回収率は約 $90 \%$ 以上であり，HS-SPME-GC-AED 測定を通じた回収率 の再現性はRSDとして $9 \%$ 以下とおおむね良好であった。 HS-SPME 操作を含めたトルエン, クロロベンゼン, 1,2-ジ クロロベンゼン及び 1,4-ジクロロベンゼンの検出下限值は それぞれ 24，25，14 及び $13 \mathrm{ppb}(S / N=3)$ であった.こ れらの值は試料量を増加させることで小さくすることが可 能であり, 本法は, 抽出条件などを最適化すれば環境水中 の芳香族炭化水素類の定量に適用できると考えられる.

\section{4 結 言}

重水素置換体を内標準物質として用いた芳香族炭化水素 の定量を RFP-AEDを備えた GCにより行った. AED 単体 では水素と重水素のスペクトル上での完全分離は達成でき なかったものの, GC-AED としては分離が可能であった. 本法を HS-SPME により抽出濃縮した水道水中の芳香族炭 化水素分析に適用し, ppbレベルの定量が可能であること を示した. 本 AED は小型でかつ単純な装置構成での測定 が可能である. 今後, バックグラウンドノイズの低減化や,
より高い波長分解能を有する分光器を使用することなどに より, 高感度かつ高選択的な可搬型分離分析システムへの 応用が期待される.

$$
\text { 謝辞 }
$$

本研究の一部はJST 先端計測分析技術・機器開発事業に より行われた。この場を借りて厚く御礼申し上げる.

\section{文献}

1) S.-M. Wang, M.-Y. Wu, R. H. Liu, R. J. Lewis, D. V. Canfield : Forensic Toxicol., 24, 23 (2006).

2) 野々瀬菜穂子, 日置昭治, 倉橋正保, 久保田正明: 分析化学 (Bunseki Kagaku), 47, 239 (1998).

3) K. Yamashita, R. Nakagawa, M. Okuyama, S. Honma, M. Takahashi, M. Numazawa : Steroids, 73, 727 (2008).

4) L. C. Thomas, T. L. Ramus : J. Chromatogr. A, 586, 309 (1991).

5) W. Elbast, F. Besacier, D. Deruaz, J. L. Brazier : J. Chromatogr. B, 690, 115 (1997).

6) A. J. McCormack, S. C. Tong, W. D. Cooke : Anal. Chem., 37, 1470 (1965).

7) C. I. M. Beenakker : Spectrochim. Acta, Part B, 31, 483 (1976).

8) B. D. Quimby, J. J. Sullivan : Anal. Chem., 62, 1027 (1990).

9) W. R. Mclean, D. L. Stanton, G. E. Penketh : Analyst, 98, 432 (1973).

10) G. Becker, A. Colmsjö, K. Janák, U. Nilsson, C. Östman : J. Microcol. Sep., 8, 345 (1996).

11) Y. Juillet, E. Gibert, A. Bégos, B. Bellier : Anal. Bioanal. Chem., 383, 848 (2005).

12) P. L. Wylie, B. D. Quimby : J. High Resolut. Chromatogr., 12, 813 (1989).

13) R. J. Skelton, K. E. Markides, M. L. Lee, P. B. Farnswoth : Appl. Spectrosc., 44, 853 (1990).

14) T. N. Asp, S. P.-Bjergaard, T. Greibrokk : J. Chromatogr. A, 736, 157 (1996).

15) D. A. Ryan, S. M. Argentine, G. W. Rice : Anal. Chem., 62, 853 (1990).

16) S. P. Bjergaard, T. N. Asp, T. Greibrokk: Anal. Chim. Acta, 265, 87 (1992).

17) R. J. Skelton Jr, H.-C. K. Chang, P. B. Farnsworth, K. E. Markides, M. L. Lee : Anal. Chem., 61, 2292 (1989).

18) S. P.-Bjergaard, T. Greibrokk : Anal. Chem., 65, 1998 (1993). 
19) G. W. Rice, A. P. D’Silvia, V. A. Fassel : Spectrochim. Acta, 40, 1573 (1985).

20) S. P. Bjergaard, T. Greibrokk : J. Microcol. Sep., 65, 11 (1994).

21) J. C. T. Eijkel, H. Stoeri, A. Manz : Anal. Chem., 72, 2547 (2000).

22) J. C. T. Eijkel, H. Stoeri, A. Manz : Anal. Chem., 71, 2600 (1999)

23) R. S. Braman, A. Dynako: Anal. Chem., 40, 95 (1968).

24) 中釜達朗, 森田悦昭, 前田恒昭, 内山一美, 保母敏 行：分析化学 (Bunseki Kagaku), 51, 993 (2002).

25) T. Nakagama, T. Morita, T. Maeda, K. Uchiyama, T.
Hobo : Anal. Sci., 17 (suppl), i851 (2001).

26) 斉藤 望, 角川 淳, 中釡達朗, 内山一美：分析 化学 (Bunseki Kagaku), 56, 729 (2007).

27) T. Nakagama, T. Maeda, K. Uchiyama, T. Hobo : Analyst, 128, 543 (2003).

28）江口裕子, 中村香織, 遠藤史宏, 西山尚秀, 中釜達 朗, 清野信子, 篠田正紀, 内山一美：分析化学 (Bunseki Kagaku), 54, 869 (2005).

29) M. Khajeh, Y. Yamini, J. Hassan : Talanta, 69, 1088 (2006).

30) NIST Atomic Spectra Database (ver. 4), available from < http://www.nist.gov/pml/data/asd.cfm>, (accessed 2012-3-10).

\title{
Determination of Aromatic Pollutants in Tap Water by a
}

\section{Gas Chromatograph Equipped with a Finger-sized Atomic Emission Detector Using Deuterated Internal Standards}

\author{
Ryutaro HirAnO ${ }^{1}$, Tatsuro NAKAgAmA ${ }^{\circledR 2}$, Hizuru NAKAJIMA ${ }^{1}$, \\ Hulie ZENG ${ }^{1}$ and Katsumi UCHIYAMA ${ }^{1}$ \\ ${ }^{\circledR}$ E-mail : nakagama.tatsurou@nihon-u.ac.jp
}

${ }^{1}$ Department of Applied Chemistry, Graduate School of Urban Environmental Sciences, Tokyo Metropolitan University, 1-1, Minamioosawa, Hachioji-shi, Tokyo 192-0397

${ }^{2}$ Department of Applied Molecular Chemistry, College of Industrial Technology, Nihon University, 1-2-1, Izumicho, Narashino-shi, Chiba 275-8575

(Received April 1, 2012 ; Accepted June 19, 2012)

Aromatic pollutants (toluene, chlorobenzene, 1,2-dichlorobenzene and 1,4-dichlorobenzene) and their deuterium substitutes were determined by a gas chromatograph equipped with a finger-sized atomic emission detector (AED) using helium radio-frequency plasma. Incomplete spectral separation between the atomic emissions of hydrogen and deuterium at $656.28 \mathrm{~nm}$ and $656.10 \mathrm{~nm}$, respectively, was performed using a small CCD spectrometer (optical resolution : $0.035 \mathrm{~nm}$ ). The emissions were, however, possible to be measured separatively, due to complete gas-chromatographic separation between the aromatics and their corresponding deuterium substitutes using a GC capillary column. When the flow rate of the make-up (helium) gas, applied power and frequency were optimized to be $5 \mathrm{~mL} \mathrm{~min}^{-1}, 20 \mathrm{~W}$ and $220 \mathrm{kHz}$, respectively, the detection limits $(3 \sigma)$ of hydrogen in toluene and deuterium in toluene- $d_{8}$ were estimated to be $28 \mathrm{pg}$ and $42 \mathrm{pg}$, respectively. The aromatic pollutants in tap water extracted by head-space solid-phase microextraction were successfully determined by the GC-AED at the ppb level using deuterium-substituted surrogated compounds as the internal standards.

Keywords : gas chromatography; atomic emission detector ; deuterated internal standard. 